\title{
Stanisław Otok
}

\section{REGIONAL DIFFERENTIATION OF THE WORLD'S SOCIAL SITUATION}

The regional differentiation of the world's social situation, which I would like to present in my paper, is based entirely upon social indices. The social indices are those - I believe — which determine population's living standards and conditions. These are both indices of material situation as well as those which indicate the degree of the realization of population's aspirations, a general accessibility to cultural achievements, and the participation in social life. I have decided to base my study upon five indices: (1) quality of nourishment (amount of proteins consumed), (2) expectation of life, (3) hospital treatment, (4) access to education, (5) participation in cultural activities.

A full statistical documentation is available for all the attributes characterizing population's living standards in the particular countries. Moreover, the selected indices fulfil normal requirements of the technique adopted in the regionalization procedure, namely, the degree of mutual correlation is low but the coeficient of spatial differentiation is high. The selected indices of the level of scial situation are recognized as attributes in the regionalization procedure. Since various measures are used to denote their values, the indices are normalized and thus their summing up is made possible. Specific values ( $\xi$ ) obtained by substracting the arithmetic mean $(\bar{x})$ from any value of the investigated variable in the series of attribute $x$, divided by the value of standard deviation $(\sigma)$, are called here normalized attributes and can be obtained on the basis of the following formula: $\xi_{\mathrm{i}}=\frac{x_{l}-\bar{x}}{\sigma}$.

In practice all these normalized values fall within the range of -3 to +3 according to the law of $3 \sigma$. Thus, any attribute, expressed in any measure, becomes, after normalization, abstract number from -3 to +3 . The ordering function $F$, which follows the normalization, reads: $F=1 / n\left(\xi_{1}+\xi_{2}+\xi_{3}+\ldots \xi_{n}\right)$. Quantities obtained on the basis of the cal- 
culation described above are called the "indices of the situation" in consideration of the given pattern of the attributes.

The indices of the situation are a basis on which the units (countries) are arranged according to the values of the function. This, in turn, is the point of departure for grouping the countries into regions, uniform from the point of view of the indices (attributes) adopted.

The grouping is made by means of the analytical method, the graphic picture of which is an ogive. ${ }^{1}$ According to the adopted method, the ordered statistical series is divided into homogenous and full groups-regions. This is a grouping by means of linear ordering on the basis of one global attribute, i.e. the function depending on all the attributes of the series.

By means of this procedure four groups of countries with various social situations in the $1970 \mathrm{~s}$ are obtained. Fig. 1 presents the ogive with the singled out groups of countries.

Regional differentiation of the world's social situation. ${ }^{2}$

\section{Group I (25 countries)}

in Asia: 6 Yemen, 9 Afghanistan, 11 Nepal, 21 Bangladesh, 24 Pakistan, 25 India

in Africa: 1 Upper Volta, 2 Guinea, 3 Niger, 4 Mozambique, 5 Mali, 7 Ethiopia, 8 Burundi, 10 Chad, 12 Central African Republic, 13 Somalia, 14 Sierra Leone, 15 Mauritania, 17 Nigeria, 18 Angola, 19 Benin, 20 Liberia, 22 Senegal, 23 Rwanda

in Latin America: 16 Haiti

\section{Group II (41 countries)}

in Asia: 26 Cambodia, 28 Laos, 30 Saudi Arabia, 34 Birma, 44 Indonesia, 48 Thailand, 49 Iran, 54 Jordan, 56 Vietnam, 60 Sri Lanka, 61 Malesia, 62 Iraq, 63 Philippines

in Africa: 27 Tanzania, 29 Zair, 31 Uganda, 32 Malawi, 33 Sudan, 35 Madagascar, 37 Togo, 39 Morocco, 40 Libya, 41 Ghana, 42 Ivory Coast, 45 Cameroon, 46 Tunisia, 47 Lesotho, 57 Kenya, 52 Algeria, 53 Congo, 55 Zambia, 57 Egypt

1 I used this method in my study on the regionalization of Australia in 1970, which was published under the title Regionalizacja Ekonomiczna Australii (Economic Regionalization of Australia), University of Warsaw, 1971.

2 Countries are arranged according to the values of the ordering function and places on the diagram of the agive. 



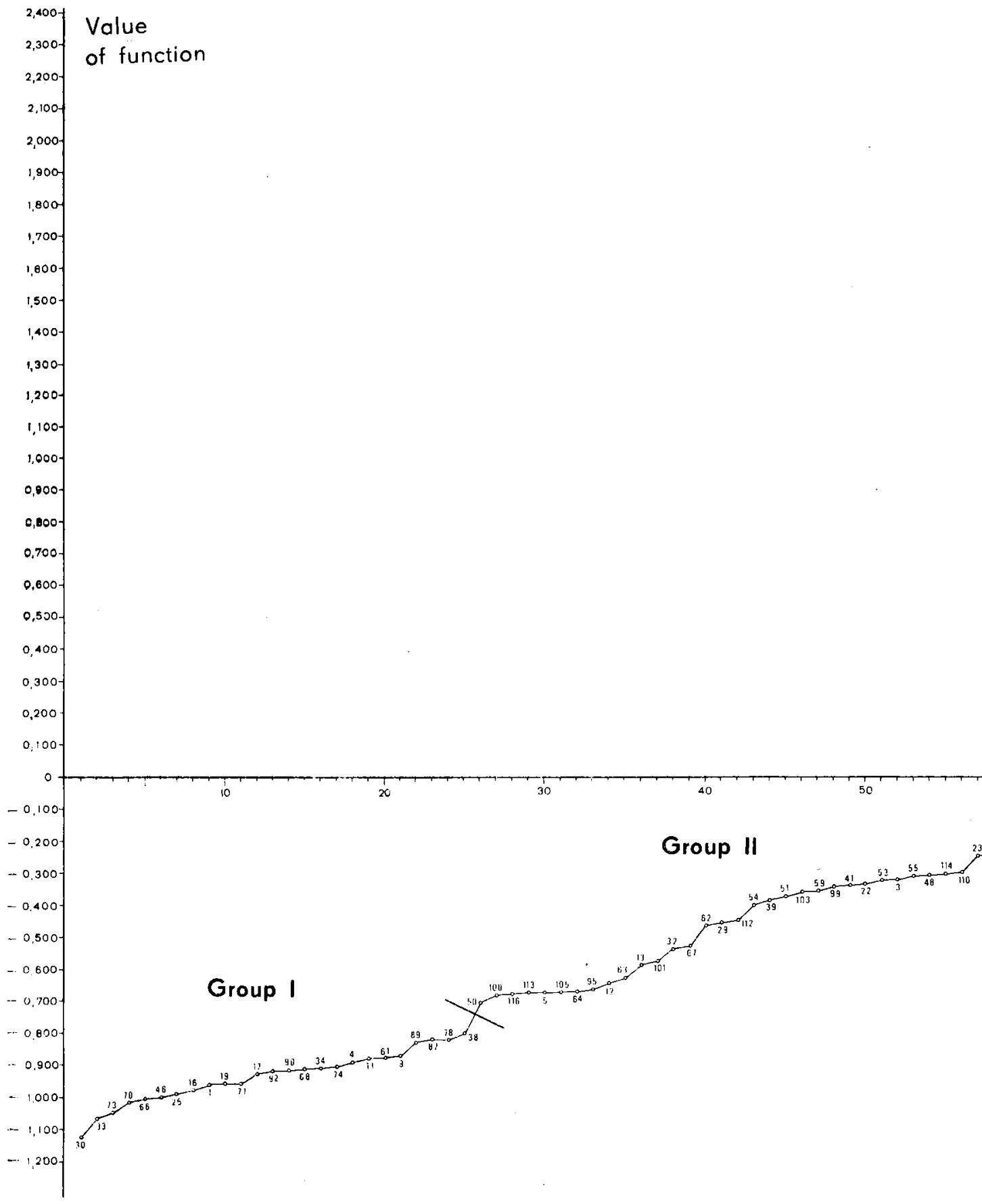

Fig. 1. Grouping of countries 


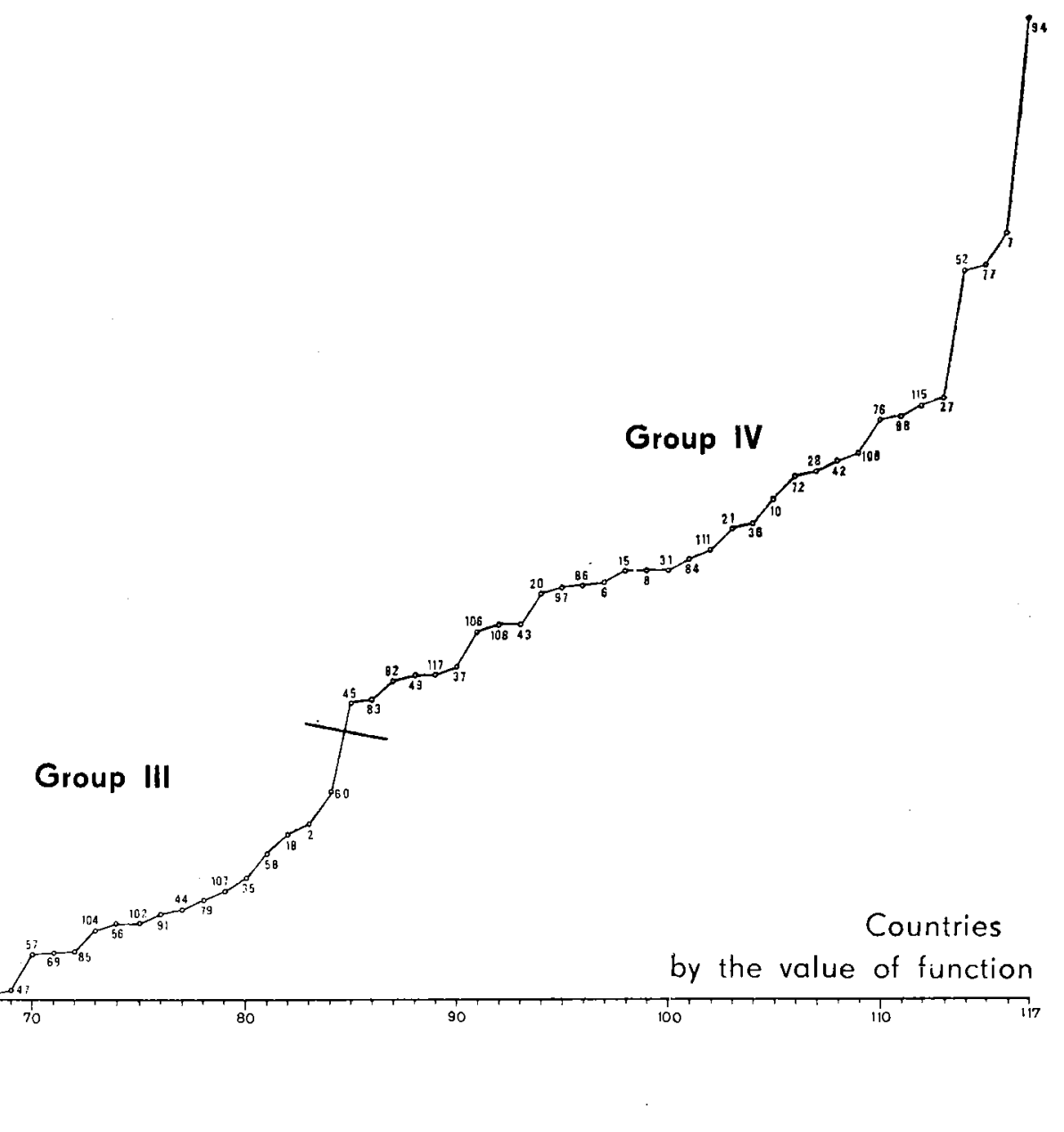



in Latin America: 36 Bolivia, 38 Guatemala, 43 Colombia, 50 Dominican Republic 58 Salvador, 59 Ecuador, 64 Nicaragua, 65 Pararaguay, 66 Peru

Group III (18 countries)

in Asia: 68 Syria, 69 Southern Yemen, 73 Turkey, 74 South Korea, 76 Singapore, 84 Lebanon

in Africa: 72 South African Republic

in Latin America: 67 Brazil, 70 Costa Rica, 71 Mexico, 75 Trinidad and Tobago, 77 Jamaica, 78 Panama, 79 Venezuela, 81 Cuba, 82 Chile

in Europe: 80 Spain, 83 Albania

Group IV (33 countries)

in Asia: 85 Japan, 89 Mongolia, 90 Hong Kong, 93 Israel

in Africa: - -

in Latin America: 91 Uruguay, 97 Argentina

in North America: 114 Canada, 117 USA

in Europe: 86 Portugal, 87 Poland, 88 Yugoslavia, 92 Hungary, 94 Czechoslovakia, 95 Switzerland, 96 Rumania, 98 Bulgaria, 99 Austria, 100 Greece, 101 Germany, Federal Republic, 102 Italy, 103 Denmark, 104 Netherlands, 106 Germany, Democratic Republic of, 107 France, 108 Ireland, 109 Great Britain, 110 Norway, 111 Sweden, 112 USSR, 113 Finland

in Oceania: 15 New Zealand, 116 Australia

The social situation of the countries in each group is characterized on the basis of the values of the attributes adopted at the initial stage of the regionalization procedure. It is presented in Tables 1 and 2 . All the indices of the social situation in the countries included in group I are under the world mean. Extreme differences appear in the expectation of life (the shortest in Upper Volta-31.6 years), in the number of hospital beds (the lowest in Afghanistan-1.7 per 10,000 people) and in the number of children under compulsory education (the lowest percentage of children between 6 and 18 under compulsory education is in Upper Volta - $9 \%$ ).

Chad, Ethiopia and Mauritania are exceptions in this group, since they exceed the world mean regarding the amount of proteins consumed; Afghanistan is almost at the world's level.

Those countries can therefore be classified as developing ones with a very bad social situation. 
Table 1

Group I

\begin{tabular}{|c|c|c|c|c|c|}
\hline \multirow[b]{2}{*}{ Country } & \multicolumn{5}{|c|}{ Attributes } \\
\hline & Proteins & $\begin{array}{l}\text { Expectation } \\
\text { of life }\end{array}$ & $\begin{array}{c}\text { No. of hos- } \\
\text { pital beds } \\
\text { per } 10,000 \\
\text { people }\end{array}$ & $\begin{array}{l}\text { No. of child- } \\
\text { ren under } \\
\text { compulsory } \\
\text { education in } \\
\text { per cent }\end{array}$ & $\begin{array}{l}\text { No. of radio } \\
\text { sets per } 1000 \\
\text { inhabitants }\end{array}$ \\
\hline 1 & 2 & 3 & 4 & 5 & 6 \\
\hline \multicolumn{6}{|l|}{ in Asia: } \\
\hline Yemen & 61 & 42,3 & 6.9 & 15 & $14 \because$ \\
\hline Afghanistan & 68 & 40.3 & 1.7 & 16 & 40 \\
\hline Nepal & 52 & 43.6 & 1.5 & 33 & 15 \\
\hline Bangladesh & 40 & 35.8 & 2.1 & 54 & 6 \\
\hline Pakistan & 52 & 51.3 & 5.3 & 32 & 16 \\
\hline India & 52 & 41.2 & 6.8 & $\overline{5} 3$ & 33 \\
\hline \multicolumn{6}{|l|}{ in Africa: } \\
\hline Upper Volta & 59 & 31.6 & $8 . \bar{z}$ & 9 & 17 \\
\hline Guinea & 45 & 40.7 & 17.0 & 22. & 26 \\
\hline Niger & 62 & 38.6 & 8.3 & 12 & 36 \\
\hline Mozambique & 41 & 43.5 & 13.0 & 30 & 24 \\
\hline Mali & 64 & 38.0 & 7.0 & 19 & 14 \\
\hline Ethiopia & 72 & 38.1 & 3.1 & 14 & 7 \\
\hline Burundi & 62 & 41.5 & 11.7 & 14 & 27 \\
\hline Chad & 75 & 32.0 & 8.6 & 22 & 19 \\
\hline Central Afri- & & & & & \\
\hline can Republic & 49 & $34 . \overline{5}$ & 19.2 & 45 & 36 \\
\hline Somal:a & $5 \overline{5}$ & 41.0 & 17.6 & 28 & 22 \\
\hline Sierra Leone & $\overline{5} 1$ & 43.5 & 10.8 & 26 & 91 \\
\hline Mauritania & 75 & 38.6 & 4.3 & 13 & 64 \\
\hline Nigeria & 62. & 37.0 & 8.6 & 29 & 79 \\
\hline Angola & 42 & 38.6 & 31.1 & 44 & 17 \\
\hline Benin & 56 & 41.0 & 13.8 & 32 & 46 \\
\hline Liberia & 39 & 43.5 & 15.3 & 38 & 152 \\
\hline Senegal & 65 & 40.0 & 11.7 & 29 & 57 \\
\hline Rwanda & 58 & 41.0 & 19.6 & $3 \bar{j}$ & 18 \\
\hline in Latin Ameri- & & & & & \\
\hline $\begin{array}{l}\text { ca: } \\
\text { Haiti }\end{array}$ & 39 & 50.0 & 9.6 & 37 & 21 \\
\hline The. world mean & 69.82 & $5 \overline{5} . \overline{5} 2$ & 41.70 & 64.69 & 195.99 \\
\hline
\end{tabular}

Certain indices of the social situation of the countries classified as group II almost reach the world mean. This is mainly true of the amount of proteins consumed (the lowest in the Congo--40.0, the highest in Paraguay-74.0) and the expectation of life (the shortest in Laos- 40 years and in the Congo- 41 years, the longest in Sri Lanka- 


\begin{tabular}{|c|c|c|c|c|c|}
\hline \multirow[b]{2}{*}{ Country } & \multicolumn{5}{|c|}{ Attributes } \\
\hline & Proteins & $\begin{array}{l}\text { Expectation } \\
\text { of life }\end{array}$ & $\begin{array}{l}\text { No. of hos- } \\
\text { pital beds } \\
\text { per } 10,000 \\
\text { people }\end{array}$ & $\begin{array}{l}\text { No. of child- } \\
\text { ren under } \\
\text { compulsory } \\
\text { education in } \\
\text { per cent }\end{array}$ & $\begin{array}{l}\text { No. of radio } \\
\text { sets per } 1000 \\
\text {,f inhabitants }\end{array}$ \\
\hline 1 & 2 & 3 & 4 & 5 & 6 \\
\hline in Asia: & & & & & \\
\hline Cambodia & 45.1 & 43.8 & 11.2 & 2.4 & 15 \\
\hline Laos & 54.2 & 40.5 & 25.0 & 52 & 58 \\
\hline Saudi Arabia & 56.0 & 45.0 & 11.9 & 35 & 29 \\
\hline Birma & 49.0 & 52.6 & 8.9 & 53 & 22 \\
\hline Indonesia & 43.0 & 47.5 & 6.2 & 57 & 37 \\
\hline Thailand & 56.0 & 56.2 & 12.4 & 62 & 129 \\
\hline Iran & 60.0 & 51.0 & 15.4 & 73 & 62 \\
\hline Jordan & 55.9 & 52.3 & 11.2 & 70 & 191 \\
\hline Vietnam & 51.1 & 44.6 & 34.2 & 92 & 43 \\
\hline Sri Lanka & 50.0 & 65.9 & 29.9 & 61 & 72. \\
\hline Malesia & 54.0 & 52.0 & 36.2 & 69 & 40 \\
\hline Iraq & 62.0 & 52.8 & 20.4 & 75 & 168 \\
\hline Philippines & 55.0 & 58.5 & 15.6 & 89 & 43 \\
\hline in Africa: & & & & & \\
\hline Tanzania & 63.0 & 44.5 & 14.3 & 43 & 19 \\
\hline Zair & 44.0 & 44.0 & 30.6 & 60 & 4.9 \\
\hline Ũganda & 61.0 & 50.0 & 15.7 & 35 & 20 \\
\hline Malawi & 63.0 & 42.6 & 17.4 & 46 & 25 \\
\hline Sudan & 65.0 & 50.0 & 10.7 & 29 & 83 \\
\hline Madagascar & 58.0 & 37.9 & 24.0 & 54 & 120 \\
\hline Togo & 56.0 & 35.0 & 14.6 & 68 & 192 \\
\hline Moroceo & 64.0 & 53.0 & 13.5 & 39 & 88 \\
\hline Libya & 62.0 & 53.0 & 44.6 & 32 & 45 \\
\hline Ghana & 47.0 & 44.0 & 15.4 & 50 & 105 \\
\hline Ivory Coast & 60.0 & $43 . \overline{5}$ & 17.0 & 56 & 155 \\
\hline Cameroon & 55.0 & 41.0 & 25.6 & 70 & 30 \\
\hline Tunisiia & 54.0 & 54.1 & 23.4 & 59 & 143 \\
\hline Lesotho & 63.1 & 46.0 & 18.1 & 79 & 19 \\
\hline Kenya & 71.0 & 49.0 & 12.9 & 69 & 37 \\
\hline Algeria & 56.0 & 53.3 & 25.8 & 59 & 173 \\
\hline Congo & 40.0 & 41.0 & 49.8 & 100 & 61 \\
\hline Zambia & 68.0 & 44.5 & 40.0 & 66 & 22 \\
\hline Egypt & 69.0 & 52.7 & 20.9 & 59 & 136 \\
\hline $\begin{array}{l}\text { in Latin Ameri- } \\
\text { ca: }\end{array}$ & & & & & \\
\hline Bolivia & 46.0 & 46.8 & 19.0 & 65 & \\
\hline Guatemala & 59.0 & 53.0 & 18.9 & 43 & 43 \\
\hline Colombia & 51.0 & 61.0 & 21.9 & 71 & 117 \\
\hline Dominican Rep. & 48.0 & 57.9 & 28.5 & 69 & 42 \\
\hline Salvador & 43.0 & 58.5 & 16.8 & 65 & 333 \\
\hline Ecuador & 47.0 & 52.4 & 20.2 & 75 & 279 \\
\hline Nicaragua & 71.0 & 52.9 & 21.1 & 63 & 260 \\
\hline Paraguay & 74.0 & 62.0 & 14.4 & 67 & 67 \\
\hline Peru & 62.0 & 54.0 & 21.6 & 89 & 134 \\
\hline The world mean & 69.82 & 55.52 & 41.70 & 64.69 & 195.99 \\
\hline
\end{tabular}



Table 4

Group IV

\begin{tabular}{|c|c|c|c|c|c|}
\hline \multirow[b]{2}{*}{ Country } & \multicolumn{5}{|c|}{ Attributes } \\
\hline & Proleins & $\begin{array}{l}\text { Expectation } \\
\text { of life }\end{array}$ & $\begin{array}{l}\text { No. of hos- } \\
\text { pital beds } \\
\text { per } 10,000 \\
\text { people }\end{array}$ & $\begin{array}{l}\text { No. of child- } \\
\text { ren under } \\
\text { compulsory } \\
\text { education in } \\
\text { per cent }\end{array}$ & $\begin{array}{l}\text { No. of radio } \\
\text { sets per } 1000 \\
\text { of inhabitants }\end{array}$ \\
\hline 1 & 2 & 3 & 4 & 5 & 6 \\
\hline \multicolumn{6}{|l|}{ in Asia: } \\
\hline Japan & 59 & 52.3 & 105.3 & 96 & 571 \\
\hline Mongolia & 94.1 & 60.7 & 106.4 & 90 & 82 \\
\hline Hong $\mathrm{K}$ ang & 84 & 69.7 & 42.4 & 98 & 2.96 \\
\hline Israel & 104.6 & 73 & 56.2 & 88 & 208 \\
\hline $\begin{array}{l}\text { in Latin Ameri- } \\
\text { ca: }\end{array}$ & & & & & \\
\hline Uruguay & 100 & 68.5 & 42.6 & 75 & 571 \\
\hline Argentina & 118 & 68.3 & 56.8 & 76 & 384 \\
\hline \multicolumn{6}{|l|}{$\begin{array}{l}\text { in North Ame- } \\
\text { rica: }\end{array}$} \\
\hline Camada & 101 & 70.0 & 92.6 & 96 & 1043 \\
\hline USA & 106 & 73.0 & 64.5 & 87 & 2048 \\
\hline \multicolumn{6}{|l|}{ iń Europe: } \\
\hline Portugal & 93 & 72.9 & 53.5 & 96 & 164 \\
\hline Poland & 110 & 72.6 & 77.5 & 88 & 241 \\
\hline Yugoslavia & 100 & 68.0 & 59.9 & 86 & 209 \\
\hline Hungary & 90 & 71.2 & 87.7 & 88 & 242 \\
\hline Czechoslovakia & 98 & 68.0 & 101.0 & 78 & 248 \\
\hline Switzerland & 88 & 69.7 & 115.0 & 68 & 343 \\
\hline Rumania & 100 & 69.7 & 92.6 & 95 & 143 \\
\hline Bulgaria & 104 & 71.2 & 87.0 & 94 & 148 \\
\hline Austria & 88 & 71.6 & 113.6 & 82 & 275 \\
\hline Greece & 104 & 71.9 & 64.1 & & 296 \\
\hline FRG & 85 & 71.6 & 119.0 & & 332 \\
\hline Italy & 98 & 71.9 & 106.0 & 86 & 2.36 \\
\hline Denmark & 89 & 74.0 & 97.1 & 92 & 366 \\
\hline Netherlands & 88 & 74.8 & 101.0 & 98 & 296 \\
\hline Belgium & 98 & 71.0 & $9 \cdot 0.1$ & 96 & 415 \\
\hline GDR & 99 & 71.5 & 107.5 & 93 & 375 \\
\hline France & 102 & 73.0 & 103.1 & 94 & 330 \\
\hline Ireland & 104 & 71.2 & 106.4 & 100 & 330 \\
\hline Great Britain & 91 & 70.8 & 85.5 & 93 & 706 \\
\hline Norway & 87 & 75.0 & 147.1 & 96 & 326 \\
\hline Sweden & 92 & 75.0 & 151.5 & 82 & 390 \\
\hline USSR & 103 & 69.5 & 120.5 & 90 & 531 \\
\hline Finland & 92. & 71.7 & 153.8 & 92 & 398 \\
\hline \multicolumn{6}{|l|}{ in Oceania: } \\
\hline New Zealand & 109 & 71.6 & 103.1 & 97 & 878 \\
\hline Australia & 106 & 71.0 & 123.5 & 83 & 1037 \\
\hline The world mean ${ }^{3}$ & 69.82 & 55.52 & 41.70 & 64.69 & 195.99 \\
\hline
\end{tabular}

${ }^{3}$ The fact that only 117 countries are included in the study is caused by lack of reliable statistical material for the remaining countries. The statistical material ficr the five attributes and 117 countries was collected by Danuta Koperska, the calculations were made by Dorota Piątkowska, M.A, and Andrzej Rajkiewicz, M.A. The main statistical material is taken from the Demographic Yearbook, U.N. 

-65.9 years and in Paraguay-62 years). The number of hospital beds per 10,000 people is in this group mostly two times lower than the world mean, with the exception of a few countries (the Congo-49.8 and Libya 44.6) where the index exceeds the world mean; the lowest value is noted in Indonesia-6.2 and Birma-8.9.

In comparison with group I the standard of education, measured by the number of children under compulsory schooling, is much higher, since, with a few exceptions (e.g. Cambodia - 24 per cent) the indices

Table 3

Group III

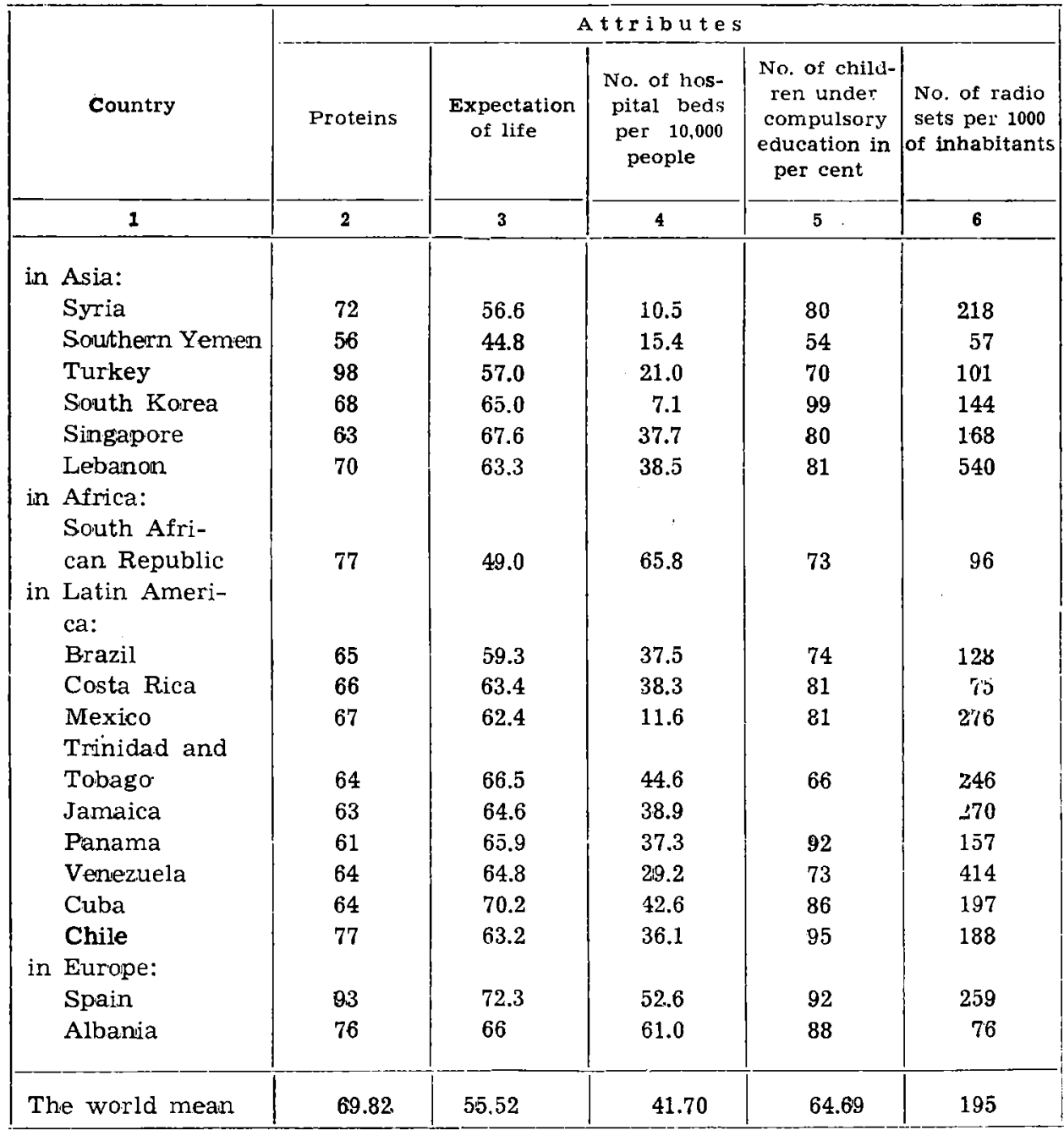


in the decisive majority of countries (three-fourths) either almost reach the world mean, or exceed it.

Altogether, those are developing countries with a higher living standard but a worse social situation than that in the world as a whole.

The indices of the amount of proteins consumed, expectation of life and compulsory schooling in the countries of group III are at the same level or almost equal to the world mean.

The situation is worse in health service (number of hospital beds per 10,000 people) with the exception of Albania, Spain, the South African Republic and Cuba, where the index exceeds the world mean, but in the majority of countries in this group the values of the index are under the world mean.

Similarly as in the previous groups the last index (the number of radio sets per 1000 of inhabitants), which is a measure of the access to mass information and also of a standard of living, is highly differentiated in this group.

In general, we may assume that group III is composed of the countries with a medium level of the social situation.

All the indices of the social situation in group IV exceed the world mean. Japan is here an exception because this country's amount of proteins consumed and the index of the expectation of life are lower than the world mean, though the remaining indices are higher. The group consists therefore of highly developed countries with a good social situation. All European socialist countries are included in this group.

The regional differentiation of the social situation and the variety of conditions 'which have produced it indicate that the social problems facing humanity are very complicated. Much time will be needed to solve them and measures should be undertaken to bring about an increased satisfaction of living conditions both of the individuals and of all the nations. 